A N N A L E S

UNIVER S T A T IS MARIAE CURIE-SKŁODOW S A LUBLIN - POLONIA

VOL. XXIX, 2

SECTIO J

2016

Drohobych Ivan Franko State Pedagogical University, Ukraine

NINA HORDIENKO

nina_gordienko@i.ua

\title{
Contemporary Family of Labour Emigrants as an Object of Socio-Pedagogical Work in Ukraine
}

\author{
Współczesna rodzina migrantów zarobkowych \\ jako obiekt pomocy społeczno-wychowawczej na Ukrainie
}

\begin{abstract}
Having analysed the contemporary labour emigration in Ukraine and challenges it poses for the family, the most important institute of the child's socialization, the author defines and supports the topicality of socio-pedagogical work with families of the emigrants. This category of families is regarded as a risk-group, malfunctioning due to irregularities in performing vital family functions; there has been also studied the issues of the distant migrant families and their impact on the child as well as peculiarities of child's socialization in case of parental deprivation. The necessity of focused and systematic work with this type of family is proved by the author's research conducted in the years 2002-2015, which allows one not only to outline the problems of the child's social formation within the distant family, but also to register retarded consequences of parental deprivation in the child's adult life. The author also presents some aspects of socio-pedagogical work with families of the emigrants.
\end{abstract}

Key words: labour emigrants; distant family; risk group; socialization; socio-pedagogical work; prevention

\section{INTRODUCTION}

A family has always been a specific mini model of the society at a particular historical stage of its development and it reflects the society's moral and spiritual values. The future of the whole country and of each individual person depends on 
the condition of a family. A family is the first and the most important institution of education that affects all the further life of a person. It is the family where children learn certain social roles and values, get to know how to interact with each other and the society, it is also the place where the personality of a child and its self-esteem is formed. "It is namely here, but not anywhere else, that we have to get down to the secrets of success in life not only of individual people, but also of entire nations" - said the famous Galician teacher P. Bilanyuk analyzing the role of family education (Bilanyuk 1939, p. 117).

Analyzing the features of a modern Ukrainian family, we have to admit that socio-economic standards of living have also affected the stability and educational ability of the family. The evidence of this is the growing number of functionally insolvent families which due to objective and subjective factors cannot effectively realize their potential, particularly, the educational function, which is certainly reflected on the features of primary socialization of children in these families. The type of family, the nature of relationships between spouses, parents and children, the participation of both parents in education and teaching, the level of their cultural development - all these factors affect the success of primary socialization of a child in the family. This conclusion is confirmed by the results of our survey upon parents (375 respondents), which indicate that the biggest impact on the formation of a child takes place in the family (39\%), while $12 \%$ of parents give preference to school in this field, and $49 \%$ of respondents, apart from the family, take into account school, peers and the media.

\section{CONTEMPORARY UKRAINIAN LABOUR EMIGRATION AND ITS IMPACT ON FAMILY FUNCTIONING}

At the turn of the $20^{\text {th }}$ and $21^{\text {st }}$ centuries, a new social phenomenon appears in Ukraine. It is so called a distant family of emigrant workers. Though the phenomenon of emigration, caused by many socio-economic factors, has a long history and different aspects of its operation, this problem and the complications related to it, are the kind of challenge today for the whole international community and for Ukraine, in particular. For almost half a decade of independent Ukrainian state, we have witnessed active debates, which were carried out in the media and by the scientific community on both positive and negative aspects of emigration. The study of this phenomenon was mostly concentrated on its demographic (mostly negative) and economic (mainly positive) consequences for Ukraine. The external aspect of the problem was analysed too. Thus, even when the Office on Employment in the Ministry of Labour and Social Policy of Ukraine reported on policy and labour emigration in the period of 2000-2005, it often stressed the fact that strengthening of labour emigration was a necessary step caused by the catastrophic state of the national labour market, so, according to it, the labour emigration 
might have become the means of preserving the family that had occurred in a difficult economic situation. Today, when Ukraine is already facing the effects of emigration on a distant family and the execution of its educational function, we can, without any exaggeration, state that none of the economic benefits is able to outweigh the social and educational role of parents who have to be close to their children and lead them in life, contributing to their social adaptation. So, what was to preserve the family, has turned against it.

The impact of labour emigration on a family functioning, on abandoned family members, particularly children, and the development of strategy of assistance the members of such families have only recently gained special interest in a domestic science. The evidence of this is presented by the researches of O. Dvizhova, N. Kub'yak, O. Penishkevych, Ya. Raevskaya, A. Taranova, I. Trubavina and others. A very significant contribution to solving the outlined problem is being made by the experts of the International Women's Rights Centre "La Strada Ukraine" and by the International Charity Foundation "Caritas Ukraine", Western Centre "Women's Perspectives".

The purpose of this article is to outline the risks that influence the very existence of a distant family and are considered as the special object of social and educational work. The achieving of this goal requires the coverage of important, in our opinion, aspects:

1) To justify the relevance of social pedagogue's work with this category of families based on the analysis of spreading the emigration phenomenon and the development of specific forms of socialization for children who come from such families;

2) To describe some aspects of social and educational work with the distant families in order to overcome and prevent the reduction of educational potential of the families and possible deformations in children's socialization.

Such factor as motivation for working abroad influences life of the families of emigrant workers and social education of children in these families. Comparative analysis of reasons for emigration in the 1990s and at present allows us to conclude that all of them are mainly economic. However, there is a tendency for changing the emigration motives. For example, according to the sociological survey "State of Modern Ukrainian Emigration in Italy", held at the end of the 1990 s, among the Ukrainian workers in Italy, the main reasons that prompted them to move abroad were: low wages (52.8\%), unemployment (31.7\%), the need to pay off debts (29.7\%) (Gorodetsky and Shehda 2003). But now the purpose of working abroad in most cases is to increase the welfare, to solve the housing issue, to finance the education of children and so on. The motives for staying abroad have been changing, the length of staying abroad is altering too which, in our deep conviction, cannot, but it affects the distant family's life, causing the problems 
of educational character, and socialization of children. As for the motives for the duration of staying abroad, the majority of Ukrainian citizens who are working abroad for a long time, declare their desire to return home as soon as possible. However, the "Declaration of Intentions" does not always come true.

According to the World Bank experts, Ukraine today is among five countries in the world that are the major donors of immigrants. Ukrainian emigration has become an accepted reality, known by everybody and widely discussed, but not enough attention is paid to it as labour emigration is often perceived one-sidedly, without taking into consideration the complex effects it causes. Lack of a permanent research on labour emigration in Ukraine that might have been carried by the state institutions and the lack of a united methodology for measuring the social group of emigrant workers make it difficult to understand the scale of the phenomenon. The problem of emigrant workers is mainly studied by non-governmental organizations that initiate researches on emigrant workers' condition and needs (including their children). Representation of such researches may raise doubts in the scientific community, but they are the only data that are available, and which reflect the totality of problems in this area. The impossibility to determine the exact number of children of emigrant workers makes it difficult to understand the scale of the issues, which directly affects the volume of measures that are necessary to solve the problem. Official data vary from 2 to 5 million Ukrainian labour emigrants abroad, while the informal sources point to 7-8 million. Only six percent of the workers do not have any children. In most emigrant families there are two or three of them. Thus, if seven million Ukrainian citizens have left the country for working abroad, there are about 7.5-9 million juveniles in today's Ukraine who live without any parental care. There are about 20,000 children only in the Lviv region whose parents are the emigrant workers; almost in every class at school there are one, two or even three students whose mom or dad, and sometimes both of the parents are working abroad.

This situation has caused a number of negative social phenomena; and it was such a social institution as a family that had undergone a colossal destruction. The problem is that when the members of the family are sprinkled around the world, it cannot fully implement its social function and has a miserable chance of being preserved. This gives the field to consider this category of the families as the families at risk, which are dysfunctional from the point of view of lack of one of its members, sometimes, both parents, a number of violations in family life, including the most common phenomena such as the changing of the system of relationships between parents and children, affecting the family system as a whole; lack of clearly examined boundaries that outline the family members and the family as a unity; high level of anxiety for such family members; unclear rules defining principles of a family life, inflexible roles and functions, etc. De- 
formation in the functioning of, at least, one element in the system of the family relationships can manifest in inconsistency of goals of adult family members to the purpose of a family system functioning, may lead to disruption of a family ties (inconsistency of objectives and rules in the family functioning as a whole system, the dominance of competition or antagonism in a family relations, which often manifests itself in subsystems "husband - wife", "father/mother - children", the lack of adequate distribution of family roles, liberal, authoritarian or even indefinite style of parenting may be observed, closed or superficial components of interactive communication). The result of the family disruption, as practice shows, is often the "broken" fates of children who are forced to "be torn" between father and mother; neglected and homeless children, who are called orphans with living parents; radical change of vital values of children that is mainly provoked by their parents, who, in most cases, try to compensate their lack of absence with everything it can only dream of. It should be noted that this situation has another side and, as the evidence shows, there is a certain change of values with both children and parents; there are many parents whose "good" intentions sometimes do more harm than good, because they are turned into an inexhaustible source of profit, into financial "donors" for their abandoned children, these parents turn their children into selfish consumers.

Thus, temporal distance of family members from each other, which is often not temporary, but, in many cases, permanent, causes not only a longing for family members, but also a number of negative changes both in the relationship between the couple themselves, and the child-parent relationship. Such situation leads to disruption of family relationships between its members provoking a number of risks that could cause deformation at different levels of family system and changes in family status, and becomes the reason for family distress.

Another peculiarity of the outlined problem is manifested in the fact that the highest intensity of labour emigration concerns divorced women who often face the problem of child's maintenance without the assistance of another parent. As practice shows, the vast majority of under aged children from such families remain with grandparents, relatives, and sometimes with just friends or older children. It is clear that these people are unable to fully perform educational duties instead of the parents.

No matter which family - full or incomplete - the emigrant parents come from, they, first of all, try to meet biological needs of children, while it is almost impossible to satisfy the child with paternal love, respect and communication being at some distance abroad. As a result, the child finds itself in a chronic traumatic situation (Blinova 2011). This may lead to many negative consequences in personal and emotional spheres of mind not only in childhood (which will affect the behaviour and studies), but will also have the influence on children's adult life. 
Among the long-term effects of parental deprivation, one of the most important problems is the one connected with the creation of their own family and future parenthood. Not being able to watch the model of a complete family, the roles of father and mother, husband and wife, children from distant families have difficulty with creating their own families and often repeat the life scenarios of their parent families.

The topicality of providing the families of emigrant workers with targeted social and educational assistance is proved by the results of our research aimed at studying the peculiarities of social formation of children from families of emigrant workers, which was launched in 2002 (Lviv region) and it has been carried out. The results suggest that there is a clear tendency of increasing the length of parents' (emigrant workers) staying abroad and the fact that there are specific risks of the existence of such a family. Today, we witness the cases when a mother or a father, the emigrant workers, actually do not participate in the social formation of their children during the entire period of study at school and after its finishing. Occasional educative influence of distant parents on children, in our opinion, does not contribute much to the education of children but, on the contrary, provokes certain strain in relationships that leads to deformation in the socialization of such children. For example, among the respondents surveyed by us in 2002, out of 115 schoolchildren, there were 17 first-grade children whose mothers had been already working abroad for more than three years. Later we learned that the parents of 10 pupils of this group were constantly working abroad throughout the whole period of their children's training at school. In the course of our study we found out that in the distant families where the parents were outside Ukraine for three or more years, the children from seemingly trouble-free but the distant families are more prone to display deviant behaviour than those who live with their parents. The evidence of this is quite a significant number of teens who are registered in juvenile delinquent services and negative changes in behaviour of the children after their parents leave such as absenteeism at school and reduced success in studying, aggression and conflict, alcohol and drugs. This situation is provoked by weakening (or, sometimes, the complete lack of it) the control of the children's behaviour and studies at school by their parents or people substituting them and the availability of material resources, the value of which the children are not ready to appreciate and sometimes are not able to appreciate. Another negative feature characteristic for the emigrant workers' children is the formation of their consumer interests; quite many of such children perceive the person (father/mother) who went to work abroad, solely through the prism of money he/she earns. For example, out of 115 respondents surveyed by us in 2002, 47\% of students (mostly seniors) said that their parents should ensure their future, while they do not see their own active part in this process. Interesting was the fact that this figure had 
risen by $16 \%$ in 2005 and was already $63 \%$ then; in 2012 it was already $69 \%$. The obtained results clearly indicate the fact that the children of emigrant workers are forming a new social group at labour market - the group of employable dependents as the expensive gifts and the money with the help of which the parents try to compensate their own absence, make their children more financially well-off in comparison with their peers. Such welfare forms the impression that there is no need to work, so after coming of age, being able to provide themselves, such children prefer to receive money from their parents abroad.

\section{LONG-TERM CONSEQUENCES OF LABOUR EMIGRATION FOR CHILDREN}

Since 2008, we have attempted to track the fates of those who were our respondents in 2002. For example, in 2008, among all the students of grades 10-11, who were our respondents at the first stage of the study, we managed to find 19 people. Eleven of them have created their own families ( 5 boys and 6 girls). Five of them ( 4 boys and 1 girl) got divorced during the first two years of married life (four families with one child). Two out of these 5 families, have already got the status of incomplete, distant one. Three out of 6 existing families, were completely dependent on their emigrant parent-workers (they neither studied, nor worked). The fate of the remaining 8 out of 19 people (who, by the time observed, have not formed their own families) can be represented as follows: 4 - have graduated from university and are in business; 2 - are registered in the drug service; 1 - is in prison; 1 respondent neither studies nor works anywhere and does not support any links neither with his mother who is an emigrant labour worker, nor with his father who has created a new family.

We should highlight some aspects of our direct communication with these already adults who spent their childhood in conditions of parental deprivation. Almost all of them said that the conditions of their childhood affected their adulthood. Though they all were quite restrained during our conversation, we could feel their pain and resentment mainly towards their mothers who once were very close to them, but left. Especially clearly it was manifested with the male representatives who, even in adult life, perceived their mother's leave for work abroad as a kind of betrayal. In this connection, we will provide an example from the life of Maxim J., whose mother left for Italy when the boy turned only 1 . Today he is a 19-year-old student. All this time the guy was brought up by his father who duly performed his duties for the child's upbringing. Our long-term interaction with this family is the proof of that. However, in our view, by this time there have already occurred some changes in his father's model of parental behaviour as he had been trying to fully substitute the missing mother and take over upon him the mother's parental functions, so his communication with his son corresponded 
more to the maternal model of the family than paternal. It should be mentioned that his father had never alienated son against his mother and constantly tried to maintain her positive image. It is worth noting that this family, being at risk, has not acquired the status of disadvantaged, though after 10 years, the family received the status of incomplete de jure (currently neither father nor mother have not created new families). As for Maxim, the guy tries to avoid contacts with his mother (even when his father insists on it). Among the most significant effects of maternal deprivation in Maxim's childhood we can highlight an entire distrust to women, difficulties in communication with girls and women, corresponding to his position "all women are potential traitors". This allows us to predict that it will be difficult for him to create his own family in the future and to ensure its competent functioning.

Our further tracking of children's fates whose childhood was spent in conditions of distant families of emigrant workers, took place in the years 2009-2014 and showed some distinct trends:

a) changing of the parental family status of labour emigrants (almost $60 \%$ of the families got the status of incomplete de jure; $21 \%$ - got the status of a dysfunctional family mainly due to alcoholism of a father who stayed with the children in Ukraine);

b) the increase of cases when the parents-labour emigrants take their under aged children out of Ukraine. It is often done illegally through a complex procedure of gathering the documents for taking the child to the country of destination;

c) reunification of Ukrainian families abroad (the arrival of men and children) - primarily in Italy, Spain and Portugal;

d) the children of the emigrant workers form a new social group of employable dependents;

e) through deformations of the family values such children have difficulty in constructing their own family lives and are not ready for responsible parenthood.

\section{COUNTERACTION AND PREVENTION DISTORTIONS OF CHILDREN'S SOCIAL AND EDUCATIONAL FUNCTIONING}

To solve the problems of labour emigrants' children, the Ministry of Education and Science of Ukraine has issued the Order No. 865 "On Socio-Educational and Psychological Work with Children of Labour Migrants" from December 28, 2006. In addition to this, in 2005 and 2008, this issue was discussed at sessions of the Ukrainian Parliament. In 2012, Ukraine adopted a Presidential Decree which approved National Strategy for prevention of child abandonment for the period 
until 2020; that was the first time done at the state level, and the families with the children where parents were the labour emigrants, were recognized socially vulnerable and the ones that needed social support.

In order to prevent various manifestations of distress and deformities in the children's social education, the priorities of a social pedagogue work should be the awareness of the parents about the possible consequences of late child's support in the new circumstances of temporary parents' absence (or one of them); the help in establishing a normal microclimate in the family where the child was left and the organization of communication at a distance; normalization of the child's relationship with both parents; stabilization and correction of interfamily relationships; prevention of the family conflicts; adaptation of the family members to family meetings and partings; activity to prevent unwanted changes in value orientations not only of the children, but sometimes of the parents themselves; activity to prevent the formation of a new social group of employable dependents; the formation of adult models, which should be independent, not fully depend on parental support, but, on the contrary, be ready to help the parents; the organization of mutual support and self-help groups and involvement of the children and parents into common cultural and leisure activities, etc.

Among the leading institutions of social, socio-educational and psychological work aimed at complex overcome the consequences of Ukrainian labour emigration on the lives of the children, youths and adolescents we can name the educational institutions (including psychological services, operating in each school), the Social Services for Families, Children and Youth, public organizations and centres of International Charity Fund "Caritas Ukraine". Thus, in our opinion, close cooperation of these institutions and establishing cooperation between them is very important.

An example of such cooperation may be the assistance of the teachers and the students of social-humanitarian faculty of the Drohobych State Pedagogical University on the project of Caritas Ukraine "Network of Social Centres for Children of Migrant Workers", the aim of which is to reduce the negative consequences of emigration for Ukrainian society by providing support to the children, whose parents are emigrant workers or are planning to go abroad. The project also aims to increase public awareness of the problems related to emigration in Ukraine. Today Caritas of Ukraine maintains seven of such social centres for children in different cities of Western Ukraine, where emigration is the most widely spread. These are: Ivano-Frankivsk, Kolomyia, Stryi, Drohobych, Brody, Boryslav and Novovolynsk. In particular, volunteer teachers from social pedagogy and correctional education department of the Drohobych State Pedagogical University have organized the courses for training specialists to work in social centres for the children of emigrant workers; the purpose of the courses was to familiarize the trainees with such peculiarity of the children in this category as socialization; with 
the content and specific of work with the parent community and the formation of appropriate skills of social and educational work with the parents and the children from the families of emigrant workers to solve the problems that are typical for this category of customers. It should be mentioned that the students - future social pedagogues and practical psychologists - have their traditional practice at social centres for the children of emigrant workers. Among the services provided by these centres are: psychological counselling, psycho-social and pedagogical correction of educationally neglected children; conducting of educational activities aimed at improving the social security of the children of emigrant workers; help and support in solving personal problems and difficulties; playing and training activities aimed at stabilizing the psychological and emotional development of the children; diverse art therapeutic work; assistance in organization of excursions, summer camps and more.

\section{CONCLUSIONS}

Modern emigration is an essential phenomenon of the global world, which poses new challenges to the society. So, summarizing the above said and taking into account socio-economic changes in our country, which currently contribute to the process of emigration, and, thus, increase the number of the distant families, the organization of social and educational work with these families does not lose its importance, requires further in-depth research in working directly with the emigrants and their families, and the development of methods to prepare the future teachers and psychologists to work with the distant families.

\section{ROMANISED REFERENCES}

About National Strategy for Prevention of Child Abandonment for the period until 2020, Decree No. 609/2012 of the President of Ukraine from 22.10.2012 [electronic resource], http: // zakon2. rada.gov.ua/laws/show/609/2012 (access: 22.12.2015).

Bilanyuk, P., De shukaty dzherel vnutrishn'oyi karnosti, «Shlyakh vykhovannya i navchannya», 1939, no. 2.

Blinova, O.E., Trudova mihratsiya naselennya Ukrayiny u sotsial'no - psykholohichnomu vymiri. Monohrafiya, Kherson 2011.

Gorodetsky, O., Shehda, N., Stan suchasnoyi ukrayins 'koyi emihratsiyi v Italiyi, «Do svitla», 2003, no. 8-9.

Zaharnytska. I., Suchasne dytynstvo v konteksti mihratsiynykh protsesiv: ukrayins'ki realiyi, «Visnyk Instytutu rozvytku dytyny. Zbirnyk naukovykh prats'», 2011, no. 17. 


\section{STRESZCZENIE}

W artykule, w oparciu o analizę współczesnej migracji zarobkowej na Ukrainie oraz wyzwań, które stawia ona przed najważniejszą instytucją socjalizacji dziecka - rodziną, zostało uzasadnione znaczenie pomocy społeczno-wychowawczej rodzinom pracowników migrujących. Autorka rozpatruje ten typ rodzin jako zagrożony i zaburzony z powodu nieprawidłowej realizacji funkcji życiowych rodziny, określa problemy takich rodzin oraz skutki istnienia rodzin na odległość z powodu migracji rodziców, przedstawia też szczegóły przebiegu socjalizacji dzieci w warunkach nieobecności rodziców. Potrzebę specjalnej i systematycznej pomocy temu typowi rodzin potwierdziły wyniki badań przeprowadzonych przez autorkę w latach 2002-2015, które pozwoliły sprecyzować problemy kształtowania postaw społecznych dzieci w rodzinach migrantów zarobkowych oraz określić długoterminowe skutki deprywacji rodzicielskiej w ich życiu dorosłym.

W artykule przedstawiono również niektóre aspekty pomocy społeczno-wychowawczej dla rodzin migrantów zarobkowych mającej na celu zapobieganie ewentualnym zaburzeniom w procesie socjalizacji dzieci.

Słowa kluczowe: migranci zarobkowi; rodzina na odległość; grupa ryzyka; socjalizacja; pomoc społeczno-wychowawcza; profilaktyka 